\title{
Perception of Employees on Internal Communication of a Leading Five Star Hotel in Malaysia
}

\author{
Zulhamri Abdullah, Ph.D. \\ Communication Department, Faculty of Modern Languages \& Communication \\ Universiti Putra Malaysia, Malaysia \\ Tel: 60-3-8946-8525Ｅ-mail: zulhamri@fbmk.upm.edu.my \\ Claina Antonette Antony, M.Sc. \\ School of Social Sciences and Humanities, Tunku Abdul Rahman College \\ Johor Branch, Malaysia \\ E-mail: caa2104@yahoo.com
}

\author{
Received: June 27, $2011 \quad$ Accepted: August 24, $2011 \quad$ Published: February 1, 2012 \\ doi:10.5539/ass.v8n2p17 URL: http://dx.doi.org/10.5539/ass.v8n2p17
}

\begin{abstract}
The purpose of this study is to determine the importance of internal communication practice of a leading five star hotel in Malaysia. It is fruitful to measure the effectiveness of internal communication as it may improve staff productivity and satisfaction. Generally, internal communication has been ignored by some Malaysian organizations. Top management personnel see the concept of internal communication as a lower priority task than external communication such as marketing and publicity. Thus, a survey research was applied to study the key concepts of internal communication. Using a purposive random sampling technique, 144 usable responses were collected from employees of a leading five star hotel. The findings show that communication is a foundational effort of organizational success. Employees are proud of their bottom-up, top-down and horizontal communication that enhance employee relations. Specifically, everyone at this five star hotel has the ability to be heard. Every effort is made to keep its employees fully informed of events and news. In other words, employees have accessed to all vital information. In addition, most employees are satisfied with their job due to regular communication activities in a pleasant atmosphere. In concluding remarks, the practices of internal communication in this hotel are crucial as it treats employees with an immense value to attain organizational objectives.
\end{abstract}

Keywords: Internal communication, Employee relations, Hotel

\section{Introduction}

With an increasingly competitive marketplace combined with the unpredictable economy periods, Malaysia has served a wakeup call emphasizing a great need for internal communication (Ibrahim, 2003). Internal communication activities frequently have a lower priority task over external communication efforts. It is believed that some organizations in Malaysia do not realize that internal communication activities can be just as critical as selling their products and services. In the absence of internal communication, it may vanish support and loyalty among staffs (Hashim, 2002). In other words, internal communication strategies are developed reactively, when there is a crisis or major event that requires communication. Moreover, some Malaysian organizations also failed to play a central role in interpreting the corporate culture to both internal and external audiences, as Monge (2007) suggested that if employees are not well informed and motivated, the quality of an organization's relationship with other publics might be affected. In other words, the organization is in danger of collapse. Hashim (2002) highlighted three rising problems in a Malaysian internal communication setting. Firstly, employees were not informed the important and relevant tools of communication and technology in the workforce to communicate. Secondly, management was not given proper trainings. Lastly, employees were not given a focus attention on the importance of communication issues. This shows that some Malaysian organizations have failed to realize the 
statement quoted by Grunig, which states "employees of an excellent organization share a common sense of mission" (Grunig, et al., 2002: 511; Grunig, 1975).

At one time, internal communication was considered a backwater in the communication world. Its role was often to make employees feel good. Michael (1995) states that in the past management seldom revealed its plans to employees because they did not have necessarily to know but in today's changing business environment, employee communication function is compelling organizations to take a serious look at communicating with employees. The challenge for an internal communicator is to convince top management that employees need to know the organizational plans, objectives and outcomes. This helps top management to communicate its goals effectively and employees strive for alignment to maximize effective management. In the nutshell, in this new era of globalization, organizations are beginning to realize that employee communication is no longer "nice to do", it is critical to succeed (Michael, 1995).

In view of this internal communication problems discussed in the literature reviews and what witnessed in this leading five star hotel is contradicting. Thus, this paper aims to determine the channels, methods and the types of internal contents used at this hotel to build shared understanding and connectedness among its people about corporate goals and activities at the hotel. Apart from that, the paper also aims to determine the process (upward, downward, lateral, horizontal communication) through which this leading five star hotel uses to communicate with its staff. Lastly, to determine the leading five star hotel's multiracial employees' perceptions about working together and how internal communication used to improve job satisfaction at the hotel. In short, this paper examines how the components of internal communication such as the structure, flow, content, climate and culture are being practiced in this leading five star hotel successfully as part of their internal communication efforts.

Internal communication study is crucial as it could improve the organizations about internal communication and communication effectiveness in order to promote and provide excellent services internally. The study also could determine more effective internal communication tactics, procedures and activities. Furthermore, this study would be able to make future managers to accept the need for understanding employee capabilities, their attitudes and skills being practiced in employee's communication. Lastly, findings from this research will benefit to many organizations in practicing effective internal communication.

The rest of the paper is organized as follows. Part two will review the previous literature to understand the main constructs. Part three presents a research methodology followed by a description of the data, data analysis, and discussion of the research findings. Finally, part four summarizes the overall conclusion with limitation of this study and suggestions for future research.

\section{Literature Review}

\subsection{Internal Communication}

Earlier studies indicated that communication is an essential element in the practice of internal communication within an organization. Woodruffe (1995) defines internal communication as treating employees with an immense value through the practices of programs to attain organizational objectives. Internal communication should not hinder the understanding of the overall organizational functions but establish clear communication linkages and internal relations to strengthen the organization. At one time, internal communication was considered a backwater in the communication world. Michael (1995) states that in the past, top management seldom revealed its plans to employees because they did not have to know necessarily but in a today's changing business environment, an employee communication function needs to be compelling, thus, organizations can take a look at communicating with employees. Several structures and policies need to be followed to ensure the effectiveness of internal communication such as employers ensuring that employees receive copies of strategies, plans, missions, and goals to be reached. Besides that, Howard (2000) states that, employers need to make face-to-face communications with the internal publics to maintain their effective internal communication. It is in fact that the backbone of their internal communications programs. Moreover, it could help managers to develop a positive working relationship with their employees, as it offers for an enhanced two-way communication.

Furthermore, proper internal communication tools are important. Kathryn (1989) also highlighted that top management expects communicators not only to inform employees and help booster morale but also craft messages that influences employees' behavior. Internal communication, which often includes traditional deliverables such as memos, newsletters are integral to keep the internal public informed. The amount of internal communication that is offered can be determined by resource availability, organizational sizes and management priorities. Monge (2007) further highlighted that all staffs should know what and how activities are performed by other employees who participate in the sequence of related operations. This in fact broadens employees awareness on internal activities carried out and may help remove barriers of communication. Kathryn (1989) concludes that 
internal communication is the hand and fist relationship of the organization. In addition, duties and responsibilities must be segregated fairly to employees in an organization to enhance strong internal relations. Lorraine (1995) added that one of the main aims of internal communication was to build a stronger internal brand. Lorraine (1995) also stated that large organizations often have weaker internal communication practices than smaller organizations because job specialization and functional segregation have reduced access to information about services being provided. In other words, small organizations have a greater assurance of effective internal communication practices. Geddie (1999) further suggested that knowledge of information should be disseminated properly in an internal communication practice. Information is the basic building block of communication. Organizations need to absorb needed information to function effectively.

Indeed, employees want to believe employers, and employers want to be believed, but the truth is that trust is often lacking and too few companies are willing to openly tackle the issues. Therefore, the internal communicator's roles are considered as an important element in the organization, regardless of the position in an organization chart. Internal communicators build trust on its employees in an organization. Internal communicators help to enhance the procedure of a certain action performed. As a management function, internal communicators encompasses several skills such as anticipating, analyzing and interpreting public opinions, attitudes, and issues that might impact, for good or ill of the organization. In the nutshell, in the globalization era, organizations begin to realize that employee communication is no longer "nice to do" but rather it is critical to business success (Michael, 1995). Moreover, communication is an essential requirement for this new breed of employee relations.

\subsubsection{Internal Communication in Hotels}

Generally, a development in a hotel industry is likely to affect communication needs and patterns. The rapid developments in the hotel industry can be concluded as the crowing of effective communication. Employees in a hotel industry are duty bound to communicate effectively to their customers (Proctor and Doukakis, 2003). In order to communicate effectively to its external publics, they must first possess a strong foundation of effective internal communication, before they proceed to enhance effective external communication. A hotel's business may be jeopardized, if staff fails to communicate (Proctor and Doukakis, 2003). The hotel's internal communication usually consists of structured communication, which directly relates to the achievement of the work goals. It includes sales and inventory reports which communicate daily with the respective departments in the hotel (Proctor and Doukakis, 2003). Departmental managers will then inform superiors and subordinates of the important information. The prime method of giving out information in the hotel industry is based on the model of cascading downward information (David, 1997). Internal communication in hotel industry usually uses various communication techniques such as newsletter, CD's, press releases, bulletins and memos to communicate information to their employees and customers. Moreover, different types of communication methods need to be practiced for different types of employee classes in the hotel. Furthermore, hotels develop employee communication skills by measuring communication effectiveness through surveys and performance appraisals (Ahles, 1991). With effective internal communication, a hotel industry shines in its ability to bring brand to its internal and external audiences.

\subsection{Theory and Model}

The practices of internal communication in organizations are crucial as it treats employees with an immense value to attain organizational objectives. This research is based on a system theory and model of strategic employee relations. The system theory explains communication events occurring within the organization (system) in relations to the external environment. Elements of system theory are input, throughput, output, outcome, feedback and environment (Severin and Tankard, 2002). The systems theory is a systematic theory explaining the "in" and "out" of message in an organization and how it is managed systematically in order to have a clear understanding on the internal messages and effective external feedbacks. As such, the systems theory has a flowing connection towards the Van Riel and Fombrun's model of employee relations. Van Riel and Fombrun (2007) explain that internal communication now constitutes of five key components. They are structure, flow, specific inputs, climate and culture. This may guide the internal communication process more systematically. Furthermore, Krone et al., (2001) in Van Riel and Fombrun, (2007) concluded that the key notion of employee relations consists of four unique roles such as efficiency, shared meaning, connectivity and satisfaction.

Having discussed the literature review and theories related to this study, three research objectives of this study are developed as follows:

1) To examine the channels, methods and the types of internal content used in this hotel.

2) To investigate the flow and process of communication practiced in this hotel.

3) To determine employees' job satisfaction and future career development. 


\section{Methodology}

\subsection{Population and Sample}

A leading five star hotel in the 600-year-old historic Malaysian city of Melaka is a subject of this research. Population here refers to the entire staffs (top management to the lower level management) of the leading five star hotels. The total population of this hotel is 231 employees. In this research, the unit of analysis is an employee (at top management and implementation levels) of the hotel. Krejcie and Morgan's (1970) table for determining the sample size is used for this research. By referring to the table, if the population is 230 (nearest to 231) the sample size should be 144. This sample size is sufficient to represent the whole population of this study.

\subsubsection{Research Design}

First, permission is sought to conduct the study by sending a formal letter to the top management. The general database of employees provided by the management is used to select respondents randomly. However, the researchers had difficulty to access detail employees' particulars due to hotel policy. With this consideration, the study is unable to use a probability sampling procedure, and this is one of the undeniable reasons for the researchers to choose non-probability sampling. Besides that, the duration and cost of the research is limited. A quantitative survey research is used because it is objective in nature and requires the variables under consideration to be measured and presented systematically. As for the data collection method, a survey questionnaire is used by distributing to respondents selected. The data collected were analyzed using SPSS software version 13.

The questionnaire is segregated into 3 parts, naming it into part 1, part 2 and part 3 . In Part 1, item constructs are developed to answer the first research objective by examining the internal channels, methods and the types of internal content used in this hotel. Thus, it will build a shared understanding and connectedness among the hotel's people about its operation to achieve its corporate goals. In Part 2, item constructs are developed to answers the second research objectives by investigating the flow and process of communication practiced in this hotel in order to communicate to its internal stakeholders. In Part 3, there are two sections set to answer the third research objective. In the first section, the researchers have set general questions to determine the perception of employees on an overall internal communication. The second section, the researchers have set questions to find out employees' job satisfaction and future career development.

\section{Results and Discussion}

\subsection{Profiles of the Respondents}

The results shows that among the 144 sample of the leading five star hotel, 83 (57.6\%) were male and 61 (42.4\%) were female. All these respondents age groups range from 18 years to 55 years and above. Most of the respondents participated in the survey were from 45-54 years old. Apart from the various age groups of employees there, this established hotel is also a blend with a mixture of other different races such as Malays, Chinese, Indians, Babas, Portuguese and the unique Chettys. The highest number of male and female respondents is Malays and Chinese respectively. For the level of education, $44 \%$ of the respondents seem to possess a degree, mostly degree in Hotel Management and Business Administration. In addition, among the 144 respondents, 102 (70.8\%) of them were in managerial positions such as directors, senior managers, managers, and assistant managers. The other remaining $42(29.2 \%)$ respondents were holding the non-managerial positions such as executives, technicians, coordinators, housekeepers, and clerks. Apart from that, around 41 (28.5\%) respondents marked 10-14 years of service and another $31(21.5 \%)$ respondents marked off their service from 15-19 years. This shows that 50\% of employees at this established hotel are still working there for a long period of time. As for the employment contract, the permanent staff ranked the highest with 96 (67\%) respondents. Knowing the demographic details of respondents is a crowing need in this study concern.

\subsection{Results for the Three Research Objectives}

As stated previously, the study focuses on three objectives which were derived by the researchers from the five employee relations components highlighted in the Van Riel and Fombrun's model. The first objective is to determine the channels, methods and the types of internal contents practiced at the well-known hotel to build shared understanding and connectedness among its internal stakeholders. The findings show that there is a consensus agreement on the importance of internal communication practiced at the hotel studied. Moreover, 113 (79\%) respondents stated they always believe any information that they received from the Hotel. Table 1 gives a clear picture of respondents' responses about the received communication about. The mean obtained is 8.93 and standard deviation is 4.062. This supports the notion that communication is the lifeblood of the organization. Thus, the organizations can enhance overall service quality and provide information to its internal publics through effective communication practices in the organization. Internal contents or internal messages are significant 
paraphernalia for a conquering internal communication practice in an organization. The internal contents which magnetize the hotel employees the most are the issues and trends affecting the hotel and community involvement of the hotel.

Furthermore, most respondents want to be kept fully informed on the bulletin board type activities the most, such as upcoming hotel events, information about the hotels' services, corporate social responsibility activities and many forth. From the results obtained, the researchers agree with Geddie (1999) who stated that knowledge of information about organization and the issues happening at the organization makes internal communication process smooth. As for the first research question; on how internal communication channels and methods are used in this hotel, to build shared understanding about corporate goals and maintain connectedness among the hotel's people. The researchers agree with Monge (2007) who highlighted that all staff should know what and how activities are performed by other employees who participate in the sequence of related operations. Evidence states that employees are open to more than 10 sources to accept information about what's going on in the hotel and around 20 familiar channels are accessible. Internal channels are vehicles used internally in an organization to circulate information from one place to another place. The most used channels are telephone (Frequency: 144) and email (Frequency: 137).

In addition, based on the past research findings, Howard (2000) stated that employers need to make face to face communication with the internal public to maintain effective internal communication. Our results support Howard's notion as shown in Table 2 about whereby face to face (Frequency 110) ranked at the third position of their daily practice among the other twenty channels found at this hotel. Apart from that, the researchers agree with Kathryn (1989) where traditional deliverables such as memos, newsletters are still integral part of the organization to keep employees informed.

One of the past research findings stated executives who know how to persuade external audiences about its events do not always know how to effectively invite its own employees to the event. This is mainly due to the choice of channels used to inform internal publics. Events are an internal opportunity created to assemble all employees together for a celebration. Inviting employees to an event should be done carefully by choosing appropriate channels to disseminate the message about the event.

As such, the researchers found out that the choice of channels is crucial, in order to make employees participated in the activities or events organized. Regarding to the system theory, this choice of channels takes place at throughput stage of systems theory. Table 3 shows clearly the preferred choice of channels used at this leading five star hotel in Malacca. The most preferred channels, $1^{\text {st }}$ choice is "Invitation". The mean obtained is 2.87 and standard deviation is 1.318 .

Overall, most of the employees strongly agree that they are an important part of the hotel and are committed to the hotel's mission. Besides that, we can see from the results, in this leading five star hotel, employees are kept fully informed on topics like upcoming hotel events etc. The channels used at this hotel make information dissemination cohesive, complete and well organized. Apart from that information on what is going on at the hotel is disseminated fresh and timely. Furthermore, employees also claimed that they received more than an adequate amount of internal messages every day. Furthermore, Kathryn (1989) argued that with proper employee awareness on internal activities, the organization helps remove barriers of internal communication. Past reviews also stated clearly that proper segregation of information using proper channels to its employees in this hotel, would definitely enhance strong internal relations. In addition, proper choice of methods, channels and tools used are the key to enhance internal communication efforts further by creating shared understanding about corporate goals and also maintain connectedness of the hotel's people.

Indeed, all research objectives are supported significantly. This reflects the importance of building a shared understanding about corporate goals and maintains connectedness among employees. In addition, when an organization like this leading five star hotel, is born, it is born together with challenges and competition. To triumph over this battle, management and employees are duty bound to communicate effectively to the internal and external public of the organization.

At this hotel, management decisions are generally communicated to every one of the employees effectively. There is a first class communication flow between employees with managerial post and non-managerial post. Both employees who hold a managerial post and non-managerial post are given an equal importance and they are being well informed by upper level management on what is going on in the hotel. Furthermore, they have had ample opportunities to express their ideas and comments to the upper level management of the hotel. Moreover, even in the busy schedule of the employers, the employees still receive subsequent feedback to their comments. Overall, all the manager led communication occurs once a month or more. Indeed, we can spot that there is an excellent 
flow of downward and upward communication. The researchers also agree with Proctor and Doukakis (2003) who stated that managers will inform superiors and subordinates of important information. This is being witness at this leading five star hotel, as the manager led communication occurs pretty frequently. In addition, there is a good communication between people in different areas of this Hotel. A great number of employees rated very satisfied for the communication practice in their department and between staff of different department in the hotel. Apart from that, the public relations team at this reputable hotel is seen as the most effective internal communicators. Having said this, we can witness there is good horizontal communication practicing here.

David (1997) stated that the prime method or process of giving out information in the hotel industry is based on the model of cascading downward information. This is true as for this hotel, as downward communication seems to occur more than the rest. The other two processes or flows in existence includes upward as we can see everyone is given a chance to give feedback. In addition, lateral or horizontal communication is also seen through inter department dealings. All types of internal communication flow used at the hotel, primarily to disseminate information about corporate activities. This leading five star hotel, blend with a mixture of employees from races such as Malays, Chinese, Indians and other different races such as Babas, Portuguese and the unique Chettys. These multiracial employees at this hotel perceive that it is important to establish a sense of internal relations at the workplace. In addition, most of the employees are very satisfied with many aspects of opportunities or privileges, given to them with regards to their job at the hotel. Apart from them, a great number of employees are very satisfied with this hotel as a workplace. The multiracial employees at this hotel liked the hotel's practices the most and followed by its work culture. From what the researchers have witnessed so far, the researchers answered the third research objective by describing multiracial employee's perception about working together and how it had improved their job satisfaction at the hotel. The researcher also agrees with David (1997) who stated job satisfaction is one of the key elements to achieve happy working environment.

In addition a great number of employees at this hotel agree that the hotel communicates all information up to date It is important to suggest the way people communicate effectively which also improve team building activities at the hotel. This leads to answering the third research question that is multiracial employees' job satisfaction and their perception on the nature of internal communication and the way to improve it. In the nutshell, researchers have the same opinion with Clemmer (1993) who stated developments in the hotel industry can be concluded as the crowing of effective internal relations (Clemmer,1993).

\section{Conclusion}

The study reported that overall, not only this leading five star hotel, is situated at a strategic location, the communication in this leading five star hotel, is also strategic and effective as they disseminate accurate and proper information timely to its employees using various internal communication tools. The researchers also concluded that communication is a foundational effort of organizational success and in this leading five star hotel, the internal publics are extremely proud of their bottom-up, top-down and horizontal communication that enhances employee relations. In other words, everyone at this leading five star hotel has the ability to be heard. Every effort is made to keep its internal public fully informed of events and decisions that affect the hotel and the employees. In other words, internal publics have accessed to all vital information. Moreover, the researchers concluded that information is the currency of communication. Just as the flow of money creates wealth, so does the rapid and steady flow of strategic information enriches and empowers an organization like this leading five star hotel. Furthermore, the researcher determined that this leading five star hotel had nurtured and sustained systematic flow of credible, timely, and relevant information. Moreover clarity is a hallmark of excellent communication. Its absence leads to confusion, complacency, even chaos. Clear and powerful messages are first and foremost carefully considered in this leading five star hotel, where most of the employees agreed that they are fully informed. With this, they do not conflict with messages. Moreover, in this leading five star hotel, any kind of conflict is solved at the root itself. The researchers also concluded that in this leading five star hotel,, each employee's vital role in communication is recognized to ensure that all employees have the capability, tools and support to fulfill their responsibilities. This is an undeniable reason to adhere high job satisfaction at this leading five star hotel. Furthermore the researcher also concluded that the structure and the process of internal communication in this leading five star hotel have reflected the fact that communication is a means, not an end, to success. In this leading five star hotel, they recognize the importance of a healthy balance between employee's life at and away from work. The best thing about being an associate at this leading five star hotel, that quality work does not go unnoticed. Moreover, employees do not go unnoticed as well, where employee's birthdays and achievements are remembered.

The researchers concluded that, humanity enlightens the employees in the practice of internal communication. With this, there has been a high efficiency in staff's attitude, workforce and perception towards the hotel. In other 
words, this leading five star hotel, has strived to create a positive, rewarding work environment for their associates over the past two decades. Employees' values such as hard work, determination, and willingness to learn are key factors to success. The researchers concluded that internal communication activities are widely practiced in several ways at this leading five star hotel, where they have annual and monthly activities with all the associates. It's a great way to practice internal relations while getting some fun and satisfaction. Moreover, the hotel's caring club, an internal club that serves the community caters opportunities to engage in charitable events like visit to the orphanages. With this, the researchers concluded that employees practicing internal relations are the heart of this leading five star hotel. Additionally, the fundamental purpose of workplace communication in this leading five star hotel was to enhance business performance and also employee communication. Moreover, the very well built foundation of effective internal communication skills had in fact leaded the organizations success. All this further concludes that the internal publics are portraying the concept of "togetherness" and "family" in their working environment. With their high level of employee relations and motivation had in fact knock down the past research findings by Lorraine (1995) stating that large organizations have weaker internal communication practices than smaller organization because functional segregation have reduced access to information provided. This leading five star hotel is a large organization known for its 5 star accreditation in Asia has in fact proved to practice effective internal communication.

Communication function builds mutual understanding between the upper level management and the staff and vice versa. Furthermore, the researchers had determined a clear answer from the research questions and research objectives set. Determining and using the right internal channels, methods and internal contents builds shared understanding and connectedness among the hotel's people about the hotel's corporate goals and also activities held at the hotel. Apart from that the researchers also concluded that getting the right communication flow makes the organization move at the right track and this also in fact lead the hotel to communicate information about its corporate activities well with its staff. In addition, the researchers also concluded getting to know the employees perception and job satisfaction at the hotel from time to time is important as any dissatisfaction or negative perception can be wiped down at the beginning itself. The researchers also concluded that, applying the right skills at the right time is important .The researchers determined the widely used skills were communication skills and presentation skills. There are several new skills such as good relationship building skills, leadership and negotiation skills. The researchers also concluded that the relationship building skill is in fact born with the coordination of organizing internal relation activities.

Moreover, basic classical skills can be practiced more effectively by putting in efforts of creativity and knowledge. Appropriate and adequate tools are included in the communication process of this leading five star hotel, where both the computer technology and the classical communication is practiced. The preferred channels are telephone and emails. Sources preferred to receive information about the activities at the hotel are from the top management and the company Intranet. Thus, the practices of internal communication in organizations are crucial as it treats employees with an immense value to attain organizational objectives.

The researchers further concluded that the practice of system theory is widely practiced in the organization. Thus, the researchers also concluded that systems theory has a flowing connection towards the Van Riel's model of Employee Relations. Van Riel and Fombrun (2007, cited in Abdullah, 2008) explains that internal communication now constitutes of five key components. These five components guide the internal communication process more systematically. The researcher chose these five components as a guide to set the objectives. And all the objectives have been met.

Furthermore, in an extended study by Krone et al, 2001 in Van Riel and Fombrun, (2007, cited in Abdullah, 2008) concluded that the key notion in an organizational communication or employee relations consists of four unique roles such as efficiency, shared meaning, connectivity and satisfaction. The researchers also concluded that this study utilized all these four roles into the three research questions set to provide an expanded description on internal communication practices. With this the researchers concludes that, this theory and model have been effectively used in this research.

In a concluding remark, the researchers concluded that in this leading five star hotel, the level of measurement is a vital aspect of a high-performance system of strategic workplace communication, but it must be undertaken with care and skill. It is fruitful to highlight the importance of employee's trust, integrity, teamwork and attributes of vital internal relations. The researchers concluded that this organization consists of a delightful potpourri of harmonious people with the finest work environment with effective internal communication practiced through the internal communicator's efforts via applying mixtures of several basic classical and new internal communication skills. 


\section{References}

Abdullah, Z. (2008). International Corporate Communication. $2^{\text {nd }}$ Ed. Kuala Lumpur: Prentice Hall.

Ahles, B. (1991). Spotlight on career development: PR skills vs. personal skills, Communication World, 6-18. Retrieved January 10, 2005, from Pro Quest database.

Clemmer, J. (1993). The coming teams: five stumbling blocks or stepping-stones to success. Communication World, 16-20. Retrieved November10, 2004, from Pro Quest database.

David, K. (1997). Quality management in the hospitality industry: part 3 recent developments. International Journal of Contemporary Hospitality management, 5(1).

Geddie, B. (1995). Public relations and Communication: a model for future. Communication World. 20-22. Retrieved November14, 2004, from Pro Quest database.

Grunig, J. E. \& Hunt, T. (1975). Managing Public Relations. New York: Holt, Rinehart and Winston.

Grunig, L. A., Grunig, J. E. \& Dozier, D. M. (2002). Excellence in public relations and communication management: A study of communication management in three countries. Mahwah, NJ: Lawrence Erlbaum Associates.

Hashim, A. (2002). Kepentingan organisasi dan komunikasi di Malaysia. Jurnal Komunikasi dan Perniagaan, 17(4), 5-13.

Howard, F. (2000). Internal practices in a service oriented firm. Journal of Marketing, 19 (11), 34 -36.

Ibrahim, M. (2003). Komunikasi dalaman sebagai praktis di organisasi. Jurnal Komunikasi, 9 (2), 7-12.

Kathryn, J. (1989). Internal relations enhances organizations performance. Journal of Marketing, 7 (1), 12-20.

Krejcie, R. V. \& Morgan, D. W. (1970). Determining sample size for research activities. Educational and Psychological Measurement, 30, 607-610.

Lorraine, L. (1995). In house communication consultancy strengthens internal brand. Communication World, 78-82. Retrieved November 11, 2004, from Pro Quest database.

Michael, C. (1995). From nice to necessity. Communication World, 20-22. Retrieved October 16, 2004, from Pro Quest database.

Monge, C. (2007). Internal Marketing and organizational behavior: a partnership in developing employee conscious at every level. Journal of Business Research, 20(1), 63-70.

Proctor, T. \& Doukakis, J. (2003). Change Management: The role of internal communication and employee development. Journal of Communication, 8 (4), 268-278.

Severin, W.J. \& Tankard, Jr. J.W. (2002). Communication Theories. $2^{\text {nd }}$ Ed. New York: Longman.

Woodruffe, H. (1995). Services Marketing. London: Pitman Publishing. 
Table 1. The distribution of employees' perceptions of receives communication about

\begin{tabular}{lcc}
\hline Receives communication about $(\mathrm{n}=144)$ & Frequency & Percent \\
\hline Issues and trends affecting the hotel's business & 21 & 14.6 \\
Community involvement of the hotel & 21 & 14.6 \\
Employee activities in the hotel & 17 & 11.8 \\
Human resources process & 14 & 9.7 \\
Key customer issues in the hotel & 13 & 9.0 \\
Competitive initiatives & 13 & 9.0 \\
Marketing programs & 10 & 6.9 \\
Compensation and bonus programs for the & 7 & 4.9 \\
employees & 7 & 4.9 \\
Products and services of the hotel & 7 & 4.9 \\
The overall financial picture of the hotel & 5 & 3.5 \\
Hotel's success stories & 3 & 2.1 \\
The hotel's strategies for the future & 2 & 1.4 \\
The hotel's capabilities & 2 & 1.4 \\
Technological developments in the hotel & 2 & 1.4 \\
Government affairs affecting the hotel & $\mathbf{1 4 4}$ & $\mathbf{1 0 0 . 0}$ \\
Total & &
\end{tabular}

Table 2. The distribution of employees' perceptions of the channels used in the hotel

\begin{tabular}{|c|c|c|c|c|c|c|c|}
\hline \multirow[t]{2}{*}{$\begin{array}{l}\text { Channels used in the hotel } \\
(\mathrm{n}=144)\end{array}$} & \multirow{2}{*}{$\begin{array}{l}\text { Daily } \\
\text { Frequency }\end{array}$} & \multirow{2}{*}{$\begin{array}{l}\text { Weekly } \\
\text { (4-5 times } \\
\text { / week) }\end{array}$} & \multirow{2}{*}{$\begin{array}{l}\text { Monthly } \\
(1-3 \text { times } \\
\text { /week })\end{array}$} & \multirow{2}{*}{$\begin{array}{l}\text { Rarely } \\
\text { (1-3 times } \\
\text { / month) } \\
\text { Frequency }\end{array}$} & \multirow{2}{*}{$\begin{array}{l}\text { Never } \\
\text { Frequency }\end{array}$} & \multirow[b]{2}{*}{ mean } & \multirow[b]{2}{*}{ s.d } \\
\hline & & & & & & & \\
\hline Telephone & 144 & - & - & - & - & 1.00 & .000 \\
\hline Electronic Mail & 137 & 7 & - & - & - & 1.05 & .216 \\
\hline $\begin{array}{l}\text { Face to face } \\
\text { meetings/supervisory }\end{array}$ & 110 & 34 & - & - & - & 1.24 & .426 \\
\hline Bulletin boards & 108 & 36 & - & - & - & 1.25 & .435 \\
\hline Memos & 104 & 18 & 20 & 1 & 1 & 1.45 & .809 \\
\hline Intranet site & 102 & 42 & - & - & - & 1.29 & .456 \\
\hline Hotel's website & 95 & 49 & - & - & - & 1.34 & .475 \\
\hline Hotel's Logo & 75 & 36 & 1 & 31 & 1 & 1.94 & 1.207 \\
\hline Hotel's Flyers & 45 & 99 & - & - & - & 1.69 & .465 \\
\hline Posters/banners at Hotel & 37 & 98 & 9 & - & - & 1.81 & .533 \\
\hline Hotel's factsheets & 22 & 88 & 34 & - & - & 2.08 & .620 \\
\hline Hotel's brochures & 22 & 106 & 16 & - & - & 1.96 & .514 \\
\hline Hotel's Magazines & 22 & 104 & 12 & 6 & - & 3.01 & .637 \\
\hline E-Newsletter & 20 & 104 & 20 & & & 4.00 & .529 \\
\hline Hotel's Annual Reports & 19 & 125 & - & - & - & 3.87 & .340 \\
\hline Printed Newsletter & 18 & 126 & - & - & - & 3.88 & .332 \\
\hline Hotel's Staff handbook & - & - & 21 & 103 & 20 & 3.99 & .535 \\
\hline $\begin{array}{l}\text { Photo collection at the } \\
\text { Hotel }\end{array}$ & 2 & 54 & 60 & 18 & - & 2.79 & .765 \\
\hline Invitation & - & 14 & 80 & 50 & - & 3.25 & .620 \\
\hline Others & - & - & - & - & 144 & 5.00 & .000 \\
\hline
\end{tabular}


Table 3. The distribution of employees' perceptions of the preferred choices of methods used in the hotel

\begin{tabular}{|c|c|c|c|c|c|c|}
\hline \multirow[t]{2}{*}{$\begin{array}{l}\text { Methods used in the } \\
\text { hotel }(\mathrm{n}=144)\end{array}$} & $1^{\mathrm{ST}}$ Choice & $2^{\mathrm{HD}}$ Choice & $3^{\mathrm{RD}}$ Choice & $\begin{array}{l}\text { Not in My } \\
\text { Top } 3\end{array}$ & & \\
\hline & Freque ncy & Frequency & Frequency & Frequency & Mean & S.d. \\
\hline Invitati on & 39 & 18 & 10 & 77 & 2.87 & 1.318 \\
\hline $\begin{array}{l}\text { Posters on bulletin } \\
\text { boards/walls }\end{array}$ & 35 & 29 & 30 & 50 & 2.66 & 1.189 \\
\hline E-mail invitation & 30 & 38 & 16 & 60 & 2.74 & 1.206 \\
\hline $\begin{array}{l}\text { Word of mouth from } \\
\text { colleagues }\end{array}$ & 16 & 20 & 22 & 86 & 3.24 & 1.064 \\
\hline Flyers at the Hotel & 12 & 23 & 16 & 93 & 3.34 & 1.022 \\
\hline $\begin{array}{l}\text { Early plans- informed } \\
\text { through Hotel's } \\
\text { calendar }\end{array}$ & 10 & 6 & 31 & 97 & 3.49 & .869 \\
\hline Hotel newsletter & 2 & 6 & 10 & 126 & 3.81 & .571 \\
\hline Brochures at the Hotel & - & 4 & & 140 & 3.94 & .330 \\
\hline Media & - & - & 9 & 135 & 3.94 & .243 \\
\hline Observers & - & - & - & 144 & 4.00 & .000 \\
\hline Others & - & - & - & 144 & 4.00 & .000 \\
\hline
\end{tabular}

